\title{
Conditions for Thermal Activation of Ngwo Clay as an Alternative Resource for Alumina
}

\section{Udochukwu Mark*, Charles Nwachukwu Anyakwo, Okechukwu Onyebuchi Onyemaobi, Chijioke Samson Nwobodo}

Department of Materials and Metallurgical Engineering, Federal University of Technology, Owerri, Nigeria

Email: *udochukwu.mark@futo.edu.ng

How to cite this paper: Mark, U., Anyakwo, C.N., Onyemaobi, O.O. and Nwobodo, C.S. (2019) Conditions for Thermal Activation of Ngwo Clay as an Alternative Resource for Alumina. Natural Resources, 10, 1-15.

https://doi.org/10.4236/nr.2019.101001

Received: December 18, 2018

Accepted: January 28, 2019

Published: January 31, 2019

Copyright $\odot 2019$ by author(s) and Scientific Research Publishing Inc. This work is licensed under the Creative Commons Attribution International License (CC BY 4.0).

http://creativecommons.org/licenses/by/4.0/

\begin{abstract}
The thermal activation of Ngwo clay from southeastern Nigeria for optimal leaching of alumina was investigated. The clay assayed $24.63 \% \mathrm{Al}_{2} \mathrm{O}_{3}$ and $52.15 \% \mathrm{SiO}_{2}$, comprising mainly kaolinite mineral and free silica or quartz. The alumina locked up in the clay structure was rendered acid-soluble by thermal activation which transformed the clay from its crystalline nature to an amorphous, porous phase or metakaolinite. The clay samples were heated at calcination temperatures of $500^{\circ} \mathrm{C}, 600^{\circ} \mathrm{C}, 700^{\circ} \mathrm{C}, 800^{\circ} \mathrm{C}$, and $900^{\circ} \mathrm{C}$ at holding times of 30,60, and 90 minutes. Uncalcined clay samples and samples calcined at $1000^{\circ} \mathrm{C}$ (holding for 60 minutes) were used in the control experiments. After leaching the resulting clay calcines in $1 \mathrm{M}$ hydrochloric acid solution at room temperature, it was observed that the clay calcines produced at $700^{\circ} \mathrm{C}$ (holding for 60 minutes) responded most to leaching. Samples calcined for 60 minutes also responded better than those held for 30 or $90 \mathrm{mi}$ nutes. Based on activation energy studies, it was observed that calcines produced at $700^{\circ} \mathrm{C}$ (for 60 minutes) had both the highest leaching response $(51.84 \%$ after 1 hour at leaching temperature of $100^{\circ} \mathrm{C}$ ) and the lowest activation energy of $25.03 \mathrm{~kJ} / \mathrm{mol}$. It is concluded therefore that Ngwo kaolinite clay should be best calcined for alumina dissolution by heating up to $700^{\circ} \mathrm{C}$ and holding for 60 minutes at that temperature. The clay deposit has potential for use as alternative resource for alumina production in Nigeria where bauxite is scarce.
\end{abstract}

\section{Keywords}

Ngwo Clay, Bauxite, Kaolinite, Alumina, Calcination, Thermal Activation, Leaching

\section{Introduction}

Primary aluminium is produced by the electrolytic reduction of alumina $\left(\mathrm{Al}_{2} \mathrm{O}_{3}\right)$ 
in the Hall-Héroult process [1] [2] [3] [4]. The alumina used is usually refined from bauxite, which has remained the most important ore for aluminium [5] [6]. About 90 percent of the world production of bauxite is used for making alumina, most of which is consumed in the manufacture of aluminium. The rest is used in the production of abrasives, refractories, chemicals used chiefly in water purification and in the manufacture of paper, petroleum catalysts, aluminous cements, materials for the purification of kerosene and other petroleum products, and for other purposes [7] [8] [9] [10]. West Africa holds the largest bauxite resources in the world [11] [12] [13]. The U.S. Geological Survey put the world bauxite reserve at about 55 billion tonnes with West Africa having the highest share of $32 \%$ [10]. It was reported that countries in the sub-region (Nigeria's neighbours) hold about one-third of the world's bauxite reserves, and the resource is sold at locally unfavorable, internationally competitive prices [10]. Bauxite deposits are found in Guinea, Sierra Leone, Ghana, Mali, Cameroon, and Gabon [11] [13] [14]. However, no such deposits have been discovered in Nigeria [13] [15]. Only minor occurrences with low concentrations of bauxite minerals are reported from some regions like Ekiti province [15] [16] [17] and the Jos Plateau [11]. Again, only the occurrence of bauxitic clay is reported from the Mambilla Plateau (the western extension of the Adamawa Highland, near the border with Cameroon) [11] [13] [18]. This shows that the raw material for manufacture of alumina (i.e. bauxite) is very scarce in Nigeria.

The high-volume consumption of aluminium in Nigeria [19] [20] and the establishment of an aluminium smelter plant at Ikot-Abasi [20] [21] call for the development of methods for producing alumina from nonbauxite alumina/aluminium bearing raw materials. The plant was shut down mainly due to challenges of procuring the feed stock [19] [20]. The kaolinitic clays are aluminous raw materials and are well distributed on a large scale in Nigeria [12] [13] [18] [22].

Kaolinite clay has the structural formula in which the silica tetrahedral layer, represented by $\left(\mathrm{Si}_{2} \mathrm{O}_{5}\right)^{2-}$ is made electrically neutral by an adjacent aluminium octahedral layer, $\mathrm{Al}_{2}(\mathrm{OH})_{4}^{2+}$ [23] [24]. Taking one silicon tetrahedral unit and one aluminium octahedral unit, the structural formula of kaolinite can be written as $\mathrm{Al}_{2}(\mathrm{OH})_{4} \cdot\left(\mathrm{Si}_{2} \mathrm{O}_{5}\right)$ or $\mathrm{Al}_{2} \mathrm{Si}_{2} \mathrm{O}_{5}(\mathrm{OH})_{4}$ or in terms of oxides as $\mathrm{Al}_{2} \mathrm{O}_{3} \cdot 2 \mathrm{SiO}_{2} \cdot 2 \mathrm{H}_{2} \mathrm{O}$. In its pure form, kaolinite has the theoretical composition of $46.54 \% \mathrm{SiO}_{2}, 39.50 \% \mathrm{Al}_{2} \mathrm{O}_{3}$, and $13.96 \% \mathrm{H}_{2} \mathrm{O}$ (equivalent to loss on ignition or LOI). This makes kaolinite the clay mineral with the highest content of alumina [25] [26]. Kaolinite clays are therefore potential sources of alumina where bauxite is scarce or depleted. In view of Nigeria's situation, the abundant reserve of kaolinitic clays is thought as a suitable substitute for bauxite from which alumina of high purity can be obtained [27].

However, the alumina content of kaolinite (and other clay minerals) is locked up in the clay structure. It can only be released or leached out after proper thermal treatment or activation [28]. As illustrated in Figure 1, four temperature ranges are important in the transformation of clays [29], namely: the drying 


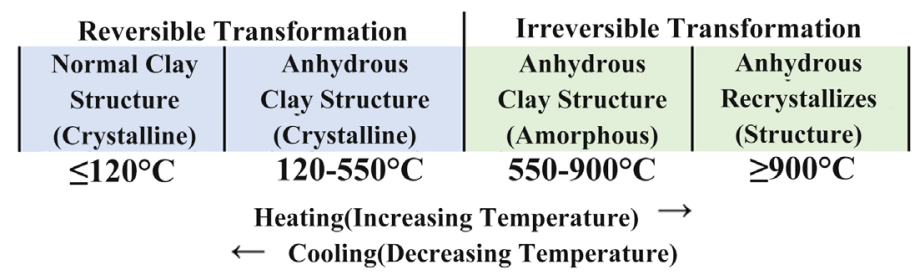

Figure 1. Effect of temperature on the physical state of clay minerals ([29], p.174).

range or free-water dehydration range $\left(50^{\circ} \mathrm{C}-120^{\circ} \mathrm{C}\right)$; the clay stability range $\left(120^{\circ} \mathrm{C}-600^{\circ} \mathrm{C}\right)$; the anhydrous clay range $\left(600^{\circ} \mathrm{C}-900^{\circ} \mathrm{C}\right)$; and the recrystallization range (above $900^{\circ} \mathrm{C}$ ).

For example, kaolinite is reported to change from hydroplastic condition to leather hard, then stone hard and finally to anhydrous condition or metakaolinite as it is heated between room temperature and about $600^{\circ} \mathrm{C}$ [30] [31]. This is because of drying, dehydration and dihydroxylation, as follows:

1) Drying or loss of wetness or physically adsorbed water by evaporation occurs at temperatures below $120^{\circ} \mathrm{C}$. The loss of physically attached water is endothermic and results in measurable weight loss. For kaolinite, the weight loss is usually minor, and the changes due to loss of physical water do not alter the crystalline structure of the clay [30]. Within the drying range, liquid water is removed from the clay, and the resulting material is referred to as leather dry or leather hard clay [31].

2) Dehydration is further loss of any remaining physically held water between $120^{\circ} \mathrm{C}$ and about $550^{\circ} \mathrm{C}$. The resulting material after this transformation is referred to as bone-dry or stone hard clay. Throughout the drying and dehydration temperature range (where physical water is removed), the expulsion of water is reversible as shown in Figure 1 [29] [31].

3) De-hydroxylation is loss of constitutional or chemically combined water (the $\mathrm{OH}$ water). Around $550^{\circ} \mathrm{C}$, the chemically combined water in clays begins to be released. This transformation continues until all chemically combined water is expelled resulting in the formation of metakaolin, an anhydrous form of kaolin. As with the loss of physically adsorbed water, the loss of the chemically combined water is an endothermic process that is accompanied by weight loss. The magnitude of the weight loss depends on the amount of chemically combined water in the clay. After de-hydroxylation, metakaolin appears amorphous on X-ray diffraction, but the short-range ordering of the cations within the sheets that make up the kaolinite structure is retained. Metakaolin is a homogeneous molecular-level mixture of non-crystalline alumina and silica and does not spontaneously rehydrate when it is exposed to water and it remains stable up to approximately $980^{\circ} \mathrm{C}$ [30] [31].

The thermal changes of kaolinite heated above $600^{\circ} \mathrm{C}$ can be outlined in accordance with the following sequence of reactions [28] [32]:

$$
\underbrace{\mathrm{Al}_{2} \mathrm{O}_{3} \cdot 2 \mathrm{SiO}_{2} \cdot 2 \mathrm{H}_{2} \mathrm{O}}_{\text {Kaolin }} \underset{\begin{array}{c}
\text { Dehydration } \\
\text { above } 600^{\circ} \mathrm{C}
\end{array}}{\longrightarrow} \underbrace{\mathrm{Al}_{2} \mathrm{O}_{3} \cdot 2 \mathrm{SiO}_{2}}_{\text {Metakaolinite }}+\underbrace{2 \mathrm{H}_{2} \mathrm{O}}_{\begin{array}{c}
\text { Constitutional } \\
\text { Water Removed }
\end{array}}
$$




$$
\begin{aligned}
& \underbrace{4\left(\mathrm{Al}_{2} \mathrm{O}_{3} \cdot 2 \mathrm{SiO}_{2}\right)}_{\text {Metakaolinite }} \underset{950^{\circ} \mathrm{C}-980^{\circ} \mathrm{C}}{\longrightarrow} \underbrace{3 \mathrm{Al}_{2} \mathrm{O}_{3} \cdot 2 \mathrm{SiO}_{2}}_{\text {Primary Mullite }}+\underbrace{\gamma-\mathrm{Al}_{2} \mathrm{O}_{3}}_{\text {Gamma-Alumina }(\mathrm{fcc})}+\underbrace{6 \mathrm{SiO}_{2}}_{\begin{array}{c}
\text { Amorphous } \\
\text { Silica }
\end{array}} \\
& \underbrace{\gamma-3 \mathrm{Al}_{2} \mathrm{O}_{3}}_{\text {Gamma-Alumina(fcc) }}+\underbrace{3 \mathrm{SiO}_{2}}_{\begin{array}{c}
\text { Amorphous } \\
\text { Silica }
\end{array}} \longrightarrow \frac{1000^{\circ} \mathrm{C}-1400^{\circ} \mathrm{C}}{\longrightarrow} \underbrace{3 \mathrm{Al}_{2} \mathrm{O}_{3} \cdot 2 \mathrm{SiO}_{2}}_{\text {Secondary Mullite }}+\underbrace{\mathrm{SiO}_{2}}_{\text {Tridymite }} \\
& \underbrace{3 \mathrm{Al}_{2} \mathrm{O}_{3} \cdot 2 \mathrm{SiO}_{2}}_{\text {Secondary Mullite }}+\underbrace{\mathrm{SiO}_{2}}_{\text {Tridymite }} \longrightarrow \frac{1400^{\circ} \mathrm{C}-1580^{\circ} \mathrm{C}}{\longrightarrow} \underbrace{3 \mathrm{Al}_{2} \mathrm{O}_{3} \cdot 2 \mathrm{SiO}_{2}}_{\text {Mullite }}+\underbrace{\mathrm{SiO}_{2}}_{\text {Cristobalite }}
\end{aligned}
$$

Thus, the thermal changes of kaolinite heated above $600^{\circ} \mathrm{C}$ progress in four major steps, namely: endothermic dehydration by de-hydroxylation of kaolinite $\left(\mathrm{Al}_{2} \mathrm{O}_{3} \cdot 2 \mathrm{SiO}_{2} \cdot 2 \mathrm{H}_{2} \mathrm{O}\right)$ to metakaolinite $\left(\mathrm{Al}_{2} \mathrm{O}_{3} \cdot 2 \mathrm{SiO}_{2}\right)$; sudden exothermic crystallization at about $980^{\circ} \mathrm{C}$ resulting to the formation of primary mullite $\left(3 \mathrm{Al}_{2} \mathrm{O}_{3} \cdot 2 \mathrm{SiO}_{2}\right), \gamma$-alumina and amorphous silica; further recrystallization to secondary mullite and tridymite; and then transformation of tridymite to cristobalite. Whereas reaction (1) or the first transformation is associated with loss in weight (due to LOI); all four transformations are accompanied by considerable volume and enthalpy changes [28].

The temperatures at which these transformations (phase changes) begin and end depends on 1) degree of crystallinity of the kaolinite, 2) its impurity oxides contents, 3) particle sizes, rate of heating, and duration of heating at a given temperature. Therefore, clays from different localities vary considerably not just in mineralogy and chemical composition, but in degree of crystallinity and purity [28] [33]. There is need to investigate the characteristics of each clay deposit. The current investigation is focused therefore on determining the thermal treatment required to transform Ngwo clay found in south-eastern Nigeria to an anhydrous amorphous phase or metakaolinite. The response of the clay calcines to alumina leaching in hydrochloric acid solution vis-à-vis the thermal treatments was also studied.

\section{Experimental Methods}

Ngwo clay deposit (Lat. $6^{\circ} 25^{\prime} 0^{\prime \prime N}$, Long. $7^{\circ} 26^{\prime} 0^{\prime \prime E}$ ) in Udi Council of Enugu state, Nigeria was sun-dried, crushed and ground. The ground clay sample was placed on a $300 \mu \mathrm{m}$ ASTM sieve and shaken for 5 minutes. The oversize was further ground and sieved on the same sieve. The procedure was repeated until the entire clay sample passed through the $300 \mu \mathrm{m}$ sieve (50 standard Tyler mesh).

\subsection{Mineralogical and Chemical Analyses}

Representative sample of the sieved clay was analysed using Pananalytical XRD (Empyrean model) to determine the constituent minerals. Optimally calcined sample of the clay was also analysed with XRD to determine the effect of thermal transformation on the clay. Similarly, the chemical composition (amounts of $\mathrm{Al}_{2} \mathrm{O}_{3}, \mathrm{SiO}_{2}, \mathrm{TiO}_{2}$, etc.) was determined by means of Buckscientific AAS (model 210 VGP). The loss on ignition (LOI) was determined by placing one gramme of dry clay sample (dried at $105^{\circ} \mathrm{C}$ for 12 hours in an oven) into a platinum crucible of known weight $\left(W_{d}\right)$. This was subsequently fired at $1000^{\circ} \mathrm{C}$ for 1 hour in a 
muffle furnace. At lapse of time, the crucible was brought out of the furnace and reweighed $\left(W_{f}\right)$ after cooling down to room temperature. The LOI was calculated in percentage as $\left(W_{d}-W_{f} / W_{d}\right) \times 100$.

\subsection{Calcination Procedures}

Ground and sieved clay samples passing $300 \mu \mathrm{m}$ sieve were subjected to thermal treatments in a muffle furnace at a heating rate of $15^{\circ} \mathrm{C}$ per minute up to the holding temperature $\left(500^{\circ} \mathrm{C}, 600^{\circ} \mathrm{C}, 700^{\circ} \mathrm{C}, 800^{\circ} \mathrm{C}\right.$ or $\left.900^{\circ} \mathrm{C}\right)$ and held for 30,60 or 90 minutes before furnace-cooling to room temperature. In addition, two sets of thermal treatment were used for the control experiment. A sample of the clay was reserved in the uncalcined condition (room temperature) and used as control 1; while another sample was heated up to $1000^{\circ} \mathrm{C}$ and held for 60 minutes and used as control 2 .

\subsection{Leaching of Clay Calcines}

Analytical grade $\mathrm{HCl}$ acid and pure deionized water were used to prepare the leaching reagent. 1 molar standard solution of hydrochloric acid was prepared using deionized water. This was used as the leaching reagent for the leaching studies to determine the leaching response of the various clay calcines and the controls. The leaching was done under moderate leaching conditions, i.e. hydrochloric acid concentration of $1 \mathrm{M}$, leaching temperature at ambient $\left(\sim 25^{\circ} \mathrm{C}\right)$, shaking speed of $100 \mathrm{rpm}$, and solid/liquid ratio or clay weight to acid volume ratio of $0.02 \mathrm{~g} / \mathrm{ml}$, using clay particles passing $300 \mu \mathrm{m}$ ( $-50 \mathrm{mesh})$.

The leach contact time or duration ranged from 0 to 120 minutes at intervals of 30 minutes. The flask or reaction bottle was shaken at a constant rate of 100 rpm during the contact time (duration of leaching) to facilitate the reaction. This was achieved by means of a KOMA orbital shaker (model KED11). By the end of leaching, the resulting slurry was filtered to separate undissolved materials (residue) from the filtrate (leachate or pregnant solution). The leachate was analysed for aluminium ion concentration.

This procedure was repeated for all the clay calcines and the control samples, which were prepared at different temperatures and duration of calcination. The optimum condition for calcining the clay was determined using solubility data (concentration and fraction of aluminium ion solubilized).

After examination of the extent of aluminium extraction or solubilization from the clay calcines, the calcine with the best leaching response for each calcination temperature was subjected to activation energy studies to establish the thermodynamic basis for their better leaching kinetics. This was in accordance with the Arrhenius rate law, viz:

$$
k=A e^{-\left(\frac{E_{a}}{R T}\right)} \text { or } \ln k=-\left(\frac{E_{a}}{R}\right) \cdot \frac{1}{T}+\ln A
$$

where, $k$ is the leaching rate constant, $A$ is the Arrhenius frequency factor, $E_{a}$ is the activation energy for the leaching reaction, $R$ is the universal gas constant 
$\left(=8.314 \mathrm{~J} \cdot \mathrm{mol}^{-1} \cdot \mathrm{K}^{-1}\right)$, and $\mathrm{T}$ is the leaching temperature on the absolute scale.

Thus, samples held for 60 minutes at different temperatures of calcination were leached in $1 \mathrm{M} \mathrm{HCl}$ at $25^{\circ} \mathrm{C}, 50^{\circ} \mathrm{C}, 75^{\circ} \mathrm{C}$ and $100^{\circ} \mathrm{C}$ for a reaction contact time of 60 minutes. All other variables such as clay particle size, shaking speed, and solid/liquid ratio were kept constant at less than $300 \mu \mathrm{m}$ ( $-50 \mathrm{mesh}), 100$ $\mathrm{rpm}$ and $0.02 \mathrm{~g} / \mathrm{ml}$, respectively. The natural logarithm of rate constants $(\ln k)$ as deduced from the solubility data (based on second-order reaction kinetics which appeared to fit the data) and the reciprocal of absolute temperature $\left(\frac{1}{T}\right)$ were used for Arrhenius plots to determine the activation energy $\left(E_{a}\right)$ in the case of each clay calcine [34].

\section{Results and Discussion}

\subsection{Type and Composition of Clay}

Ngwo clay is dominated by kaolinite mineral with free silica or quartz, and rutile as associated impurities (Figure 2). The alumina content of $24.63 \%$ (Table 1) is considered good enough for hydrometallurgical treatment of the clay as a source of alumina, and hence aluminium [6] [35] [36]. The x-ray diffraction pattern of the raw clay (Figure 2) shows the peaks for the constituent mineral phases. Similarly, Figure 3 is the XRD pattern for the optimal clay calcine showing that the sharp kaolinite peaks in Figure 2 are no longer distinct. The disappearance of the kaolinite peaks is indicative of the appearance of an amorphous phase (metakaolinite) due to thermal transformation of the clay [28]. A study of the phase transformations of kaolinite from different deposits in Russia and Ukraine showed similar results [33]. It is this amorphous metakaolinite $\left(\mathrm{Al}_{2} \mathrm{O}_{3} \cdot 2 \mathrm{SiO}_{2}\right)$ that releases alumina $\left(\mathrm{Al}_{2} \mathrm{O}_{3}\right)$ for dissolution making the clay respond to acid

Table 1. Chemical composition of Edda clay.

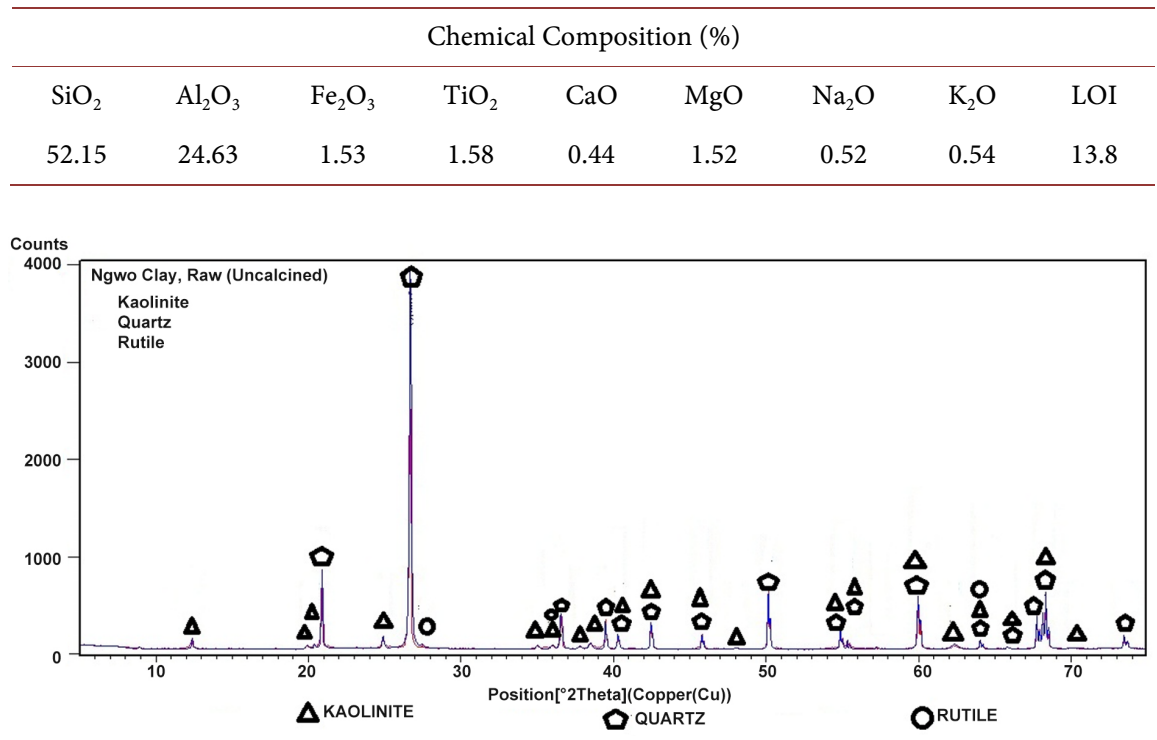

Figure 2. XRD pattern of uncalcined Ngwo clay. 


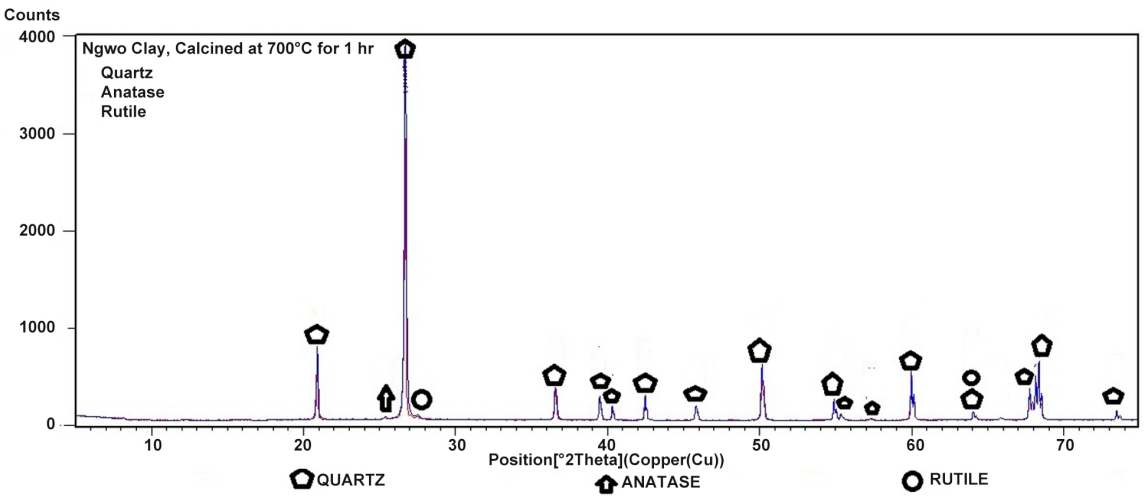

Figure 3. XRD pattern of Ngwo clay calcined at $700^{\circ} \mathrm{C}$ for 1 hour.

leaching. Thus, proper thermal treatment and transformation of the clay activates it for acid leaching [28].

\subsection{Dissolution of Alumina in Response to Acid Leaching}

The presence of $\mathrm{Al}^{3+}$ ions in the leach solutions shows that a dissolution reaction occurred between the alumina in the clay calcine and the leaching reagent. It is proposed that hydrochloric acid ionized in water to produce protons or hydrogen ions $\left(\mathrm{H}^{+}\right)$in the hydrated form known as hydronium $\left(\mathrm{H}_{3} \mathrm{O}^{+}\right)$in accordance with reaction (6) [37].

$$
\mathrm{HCl}+\mathrm{H}_{2} \mathrm{O} \rightleftharpoons \mathrm{H}_{3} \mathrm{O}_{\mathrm{aq}}^{+}+\mathrm{Cl}_{\text {aq }}^{-} \text {or } \mathrm{HCl}_{\mathrm{aq}} \rightleftharpoons \mathrm{H}_{\mathrm{aq}}^{+}+\mathrm{Cl}_{\mathrm{aq}}^{-}
$$

The dissolution of alumina $\left(\mathrm{Al}_{2} \mathrm{O}_{3}\right)$ from the clay is therefore the result of interaction between hydrogen ions $\left(\mathrm{H}^{+}\right)$and aluminium atoms of the alumina in accordance with reaction (7):

$$
\mathrm{Al}_{2} \mathrm{O}_{3} \cdot 2 \mathrm{SiO}_{2}+6\left(\mathrm{H}^{+} \mathrm{Cl}^{-}\right) \rightarrow\left(2 \mathrm{Al}^{3+} 6 \mathrm{Cl}^{-}\right)+3 \mathrm{H}_{2} \mathrm{O}+2 \mathrm{SiO}_{2}
$$

The extent of dissolution was expressed in percentage or as a fraction where the fraction of $\mathrm{Al}$ ions $\left(X_{\mathrm{Al}}\right)$ leached out of the clay into the solution was given as

$$
X_{\mathrm{Al}}=\frac{\text { concentration of } \mathrm{Al} \text { ions in the solution }}{\text { concentration of } \mathrm{Al} \text { ions in the original clay sample }}
$$

while the percent $\mathrm{Al}$ ions $(\% \mathrm{Al})$ leached out of the clay into the solution was expressed as $\% \mathrm{Al}=100 \cdot X_{\mathrm{Al}}$.

The effect of calcination temperatures at different durations of heating $(30,60$ or 90 minutes) is illustrated in Figures 4-6. It was observed that response to leaching is lowest for the uncalcined clay sample (control $1, \sim 25^{\circ} \mathrm{C}$ ) followed by that calcined at $1000^{\circ} \mathrm{C}$ (control 2). The ability of the acid $(1 \mathrm{M} \mathrm{HCl})$ to extract alumina from the clay (and enrich the leach solution with aluminium ions) varied as calcination temperature increased from $500^{\circ} \mathrm{C}$ to $900^{\circ} \mathrm{C}$. However, at $1000^{\circ} \mathrm{C}$ (control 2), the ability of the acid to attack the clay and remove alumina dropped drastically. Under 30, 60 and 90 minutes holding times (Figures 4-6); the peak leaching response occurred in the case of samples calcined at $700^{\circ} \mathrm{C}$. As 


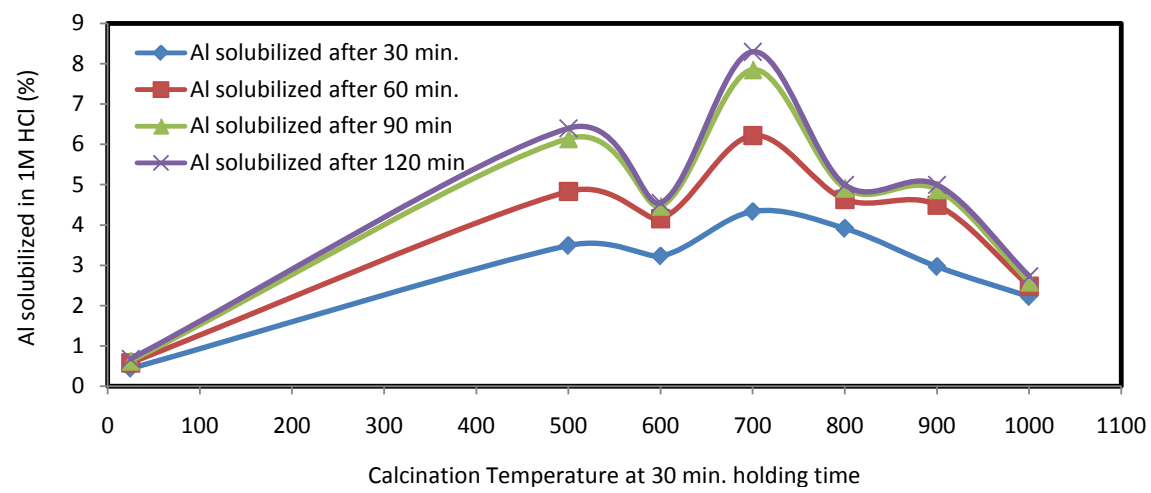

Figure 4. Effect of calcination temperature at 30 minutes holding time on the solubilization of $\mathrm{Al}$ from Ngwo clay leached at room temperature.

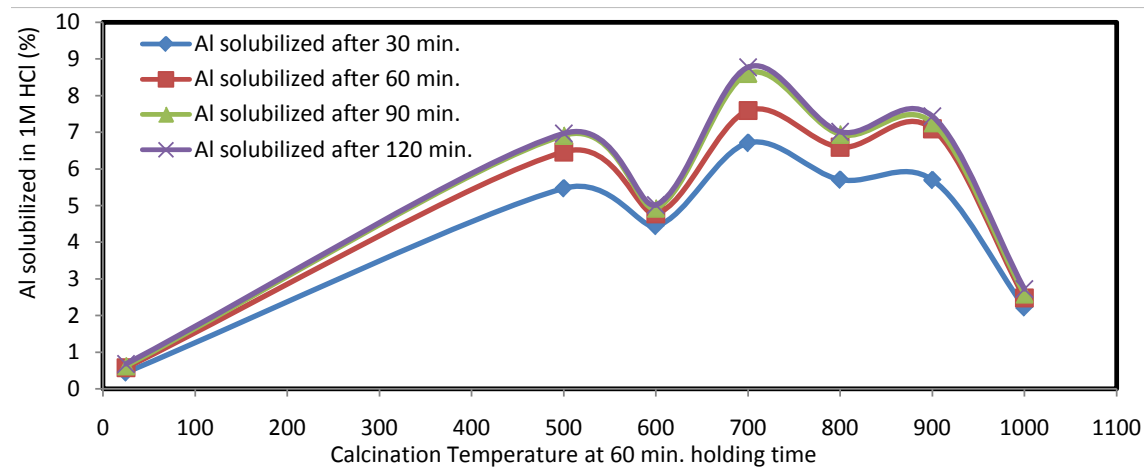

Figure 5. Effect of calcination temperature at 60 minutes holding time on the solubilization of $\mathrm{Al}$ from Ngwo clay leached at room temperature.

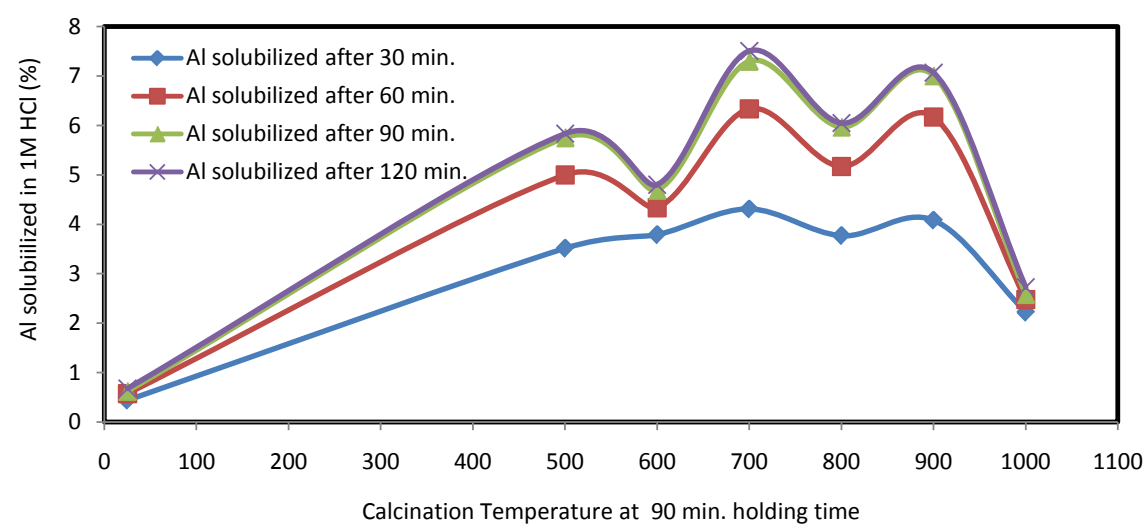

Figure 6. Effect of calcination temperature at 90 minutes holding time on the solubilization of $\mathrm{Al}$ from Ngwo clay leached at room temperature.

shown, between $500^{\circ} \mathrm{C}$ and $900^{\circ} \mathrm{C}$; the response of Ngwo clay to leaching by acid attack increased and dropped, reaching its peak at $700^{\circ} \mathrm{C}$. This behaviour is probably due to the transformation of the clay from its room temperature crystalline form (kaolinitic) to various degrees of amorphous state (metakaolinitic) and back to high temperature crystalline form at $1000^{\circ} \mathrm{C}$ and beyond, as the clay steadily lost physically combined water (through drying and dehydration) and chemically combined water (de-hydroxylation) as temperature increased. In 
other words, the clay transformed completely to an amorphous phase (metakaolinite) when it was heated to $700^{\circ} \mathrm{C}$, while crystallinity or various degrees of crystallinity existed in the clay below and above $700^{\circ} \mathrm{C}$.

\subsection{Effect of Holding Time}

It was interesting to observe that samples held for 60 minutes in the furnace responded better on leaching than those held for 30 or 90 minutes at all calcination temperatures investigated (Figure 7). For example, after 120 minutes of leaching in $1 \mathrm{M} \mathrm{HCl}$, the percent $\mathrm{Al}$ extracted in the case of samples calcined at $700^{\circ} \mathrm{C}$ were $8.29,8.77$, and $7.51 \%$ respectively for holding times of 30,60 , and 90 minutes. This means that the ability of the acid to attack alumina in the clay and remove aluminium was low at 30 minutes holding time, reached peak value at 60 minutes holding time, and declined again when holding time was extended to 90 minutes at all temperatures studied $\left(500^{\circ} \mathrm{C}, 600^{\circ} \mathrm{C}, 700^{\circ} \mathrm{C}, 800^{\circ} \mathrm{C}\right.$, and $\left.900^{\circ} \mathrm{C}\right)$. This observation could be because at 30 minutes, the transformation of the clay to amorphous (non-crystalline) state was just beginning, the transformation to amorphous metakaolinite reached advanced stage after 60 minutes but holding up to 90 minutes resulted to the reappearance of some crystallinity. Prolonged heating can therefore make the silica and alumina contents of clay to react, resulting in reduction of solubility. Furthermore, prolonged heating may also bring about the sintering of particles or phases leading to reduction in leaching response [38]. It can be concluded therefore that 60 minutes or 1 hour is the optimum calcination holding time for thermally activating Ngwo clay to respond maximally to leaching in acid.

These observations are in conformity with XRD patterns shown in Figure 2 and Figure 3 for the raw and optimally calcined clays. Thermal treatment therefore broke down the clay structure by removing the $\mathrm{OH}$ water (chemically combined) holding the network of silica tetrahedra and alumina octahedra, thus rendering the alumina acid-soluble. At sufficiently high temperatures or for prolonged heating durations, the silica and alumina recrystallized to form a crystalline and insoluble phase (e.g. mullite). It can be concluded therefore that

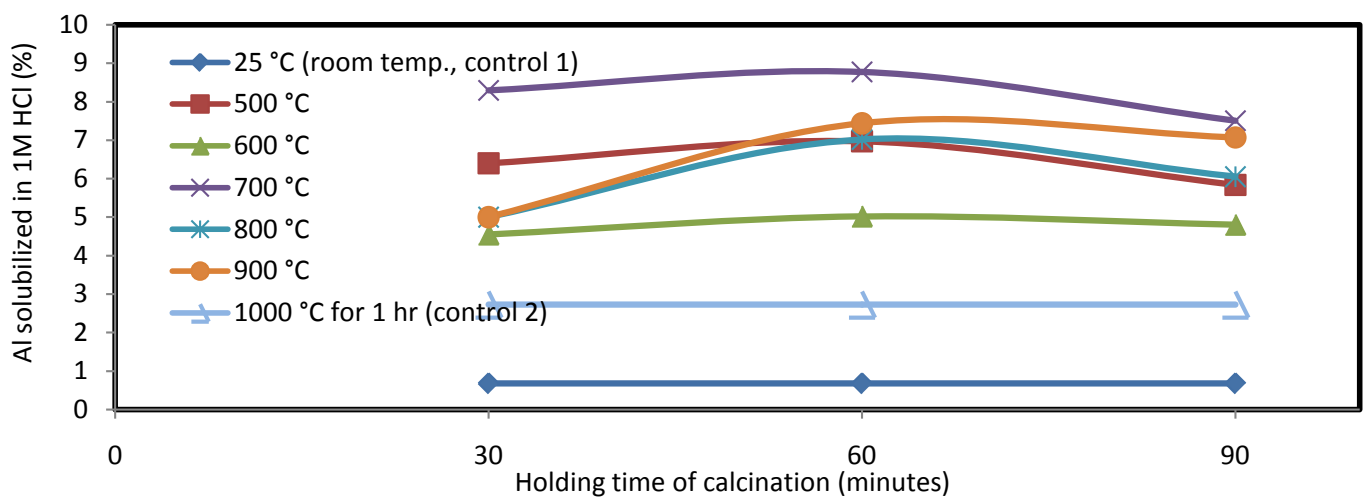

Figure 7. Effect of calcination duration (holding time) at different temperatures on solubilization of $\mathrm{Al}$ from Ngwo clay under 120 minutes leaching time. 
heating to $700^{\circ} \mathrm{C}$ and holding for 60 minutes is the optimum calcination temperature and duration for thermally activating Ngwo clay to respond optimally to acid leaching.

\subsection{Effect of Leaching Temperature and Thermal Activation}

As noted earlier, clay calcines produced by holding for 60 minutes in the furnace (at all calcination temperatures studied) responded to leaching better than those held for 30 or 90 minutes. The effect of leaching temperature on the leaching response of calcines produced under 60 minutes duration of calcination was studied further; the result is given in Figure 8. As shown, at all calcination temperatures investigated, leaching response increased as leaching temperature increased. In the case of the optimal calcine $\left(700^{\circ} \mathrm{C}\right.$ held for 60 minutes), the amounts of aluminium solubilised after leach contact time of 1 hour in $1 \mathrm{M} \mathrm{HCl}$ were $12.46 \%, 24.23 \%, 38.76 \%$, and $51.84 \%$ for leaching temperatures of $25^{\circ} \mathrm{C}$, $50^{\circ} \mathrm{C}, 75^{\circ} \mathrm{C}$, and $100^{\circ} \mathrm{C}$, respectively. It can be concluded that leaching temperature has a significant effect on the rate of alumina dissolution from the clay. This is because high temperatures enhance diffusion or mobility and hence collision frequency of reacting species in addition to providing extra thermal energy for overcoming the energy barrier or activation energy for the process. Similar observations were made by other researchers [39] [40] [41].

The effect of thermal activation on leaching of clay calcines at different leaching temperatures is also shown in Figure 8. For example, the amount of $\mathrm{Al} \mathrm{ex-}$ tracted within 1 hour of leaching in $1 \mathrm{M} \mathrm{HCl}$ at $100^{\circ} \mathrm{C}$ increased from $7.42 \%$ to $51.84 \%$ over the activation temperature range $25^{\circ} \mathrm{C}$ (for uncalcined clay) to $700^{\circ} \mathrm{C}$ (optimal calcine). Then there was a steady decline in $\mathrm{Al}$ extraction to $26.23 \%$ (for calcine produced at $1000^{\circ} \mathrm{C}$ ). Similar trends were also observed at leaching temperatures of $25^{\circ} \mathrm{C}, 50^{\circ} \mathrm{C}$ and $75^{\circ} \mathrm{C}$. This can be explained based on solid phase changes or transformations in the clay brought about by thermal treatment [38] [39] [40] [41].

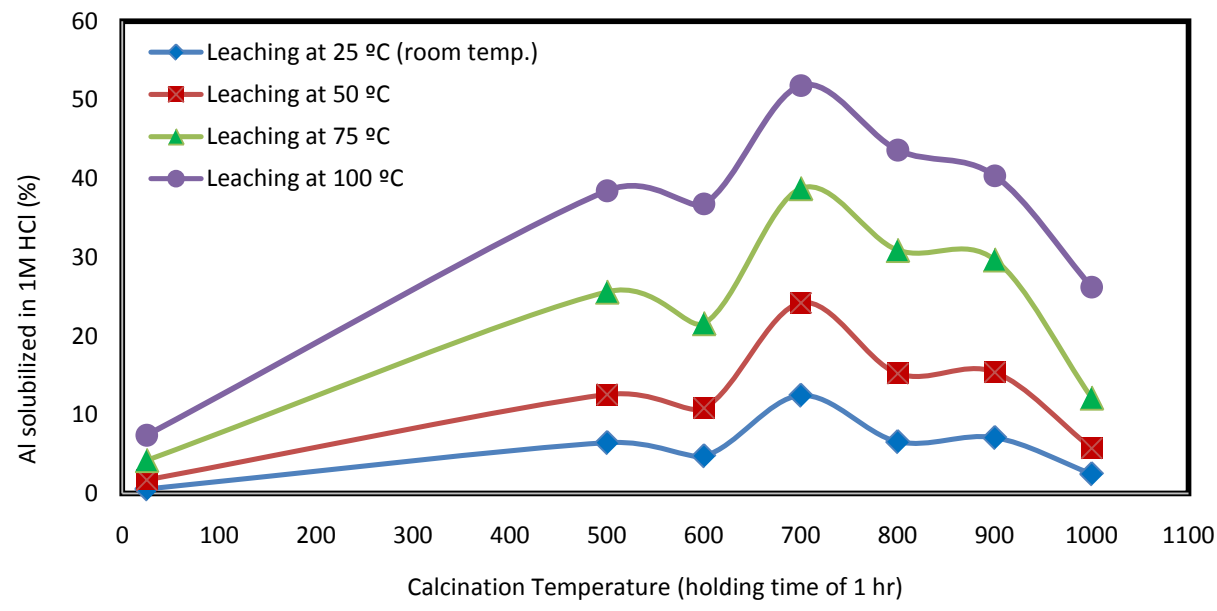

Figure 8. Effect of leaching temperature on the leaching response of selected Ngwo clay calcines within leach contact time of 60 minutes. 


\subsection{Effect Thermal Treatment on Activation Energy}

The activation energy of leaching was found to depend on the thermal treatment given to the clay. Low activation energies were obtained in the case of the clay calcines that responded well to leaching i.e. those with high level of $\mathrm{Al}$ extraction. This shows that the optimal calcination temperature and duration corresponded with the lowest activation energy (Figure 8 and Figure 10). Figure 9 shows plots of $\ln k$ versus $1 / \mathrm{T}$ for samples calcined under 60 minutes holding time and leached at different temperatures, i.e. $25^{\circ} \mathrm{C}(298 \mathrm{~K}), 50^{\circ} \mathrm{C}(323 \mathrm{~K}), 75^{\circ} \mathrm{C}$ $(348 \mathrm{~K})$ and $100^{\circ} \mathrm{C}(373 \mathrm{~K})$. The activation energies derived from Figure 9 were used to plot Figure 10. The lowest activation energy for leaching $(25.03 \mathrm{~kJ} / \mathrm{mol})$, as shown, correspond with the overall best calcine for the clay considering the aluminium solubility rate $(51.84 \%)$. Given that activation energy is the energy

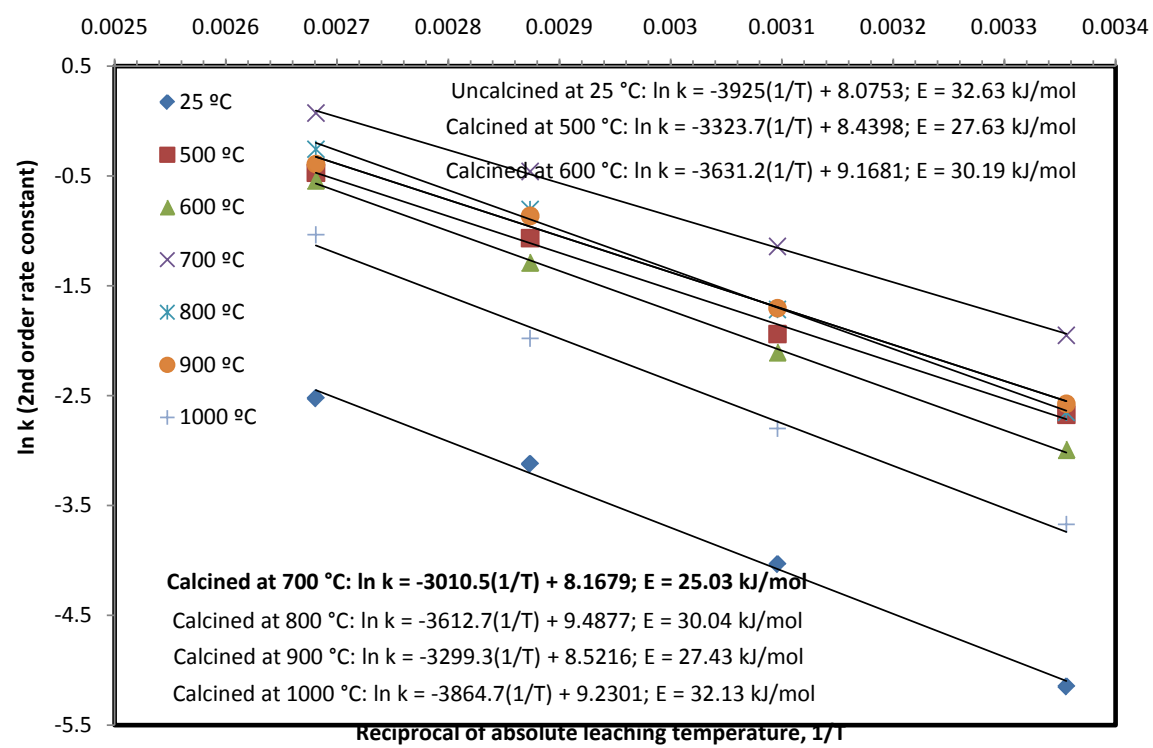

Figure 9. Arrhenius plots for the leaching of Ngwo clay calcined at various temperatures and leached in $1 \mathrm{M} \mathrm{HCl}$ at 198, 323, 348 and 373 Kelvin.

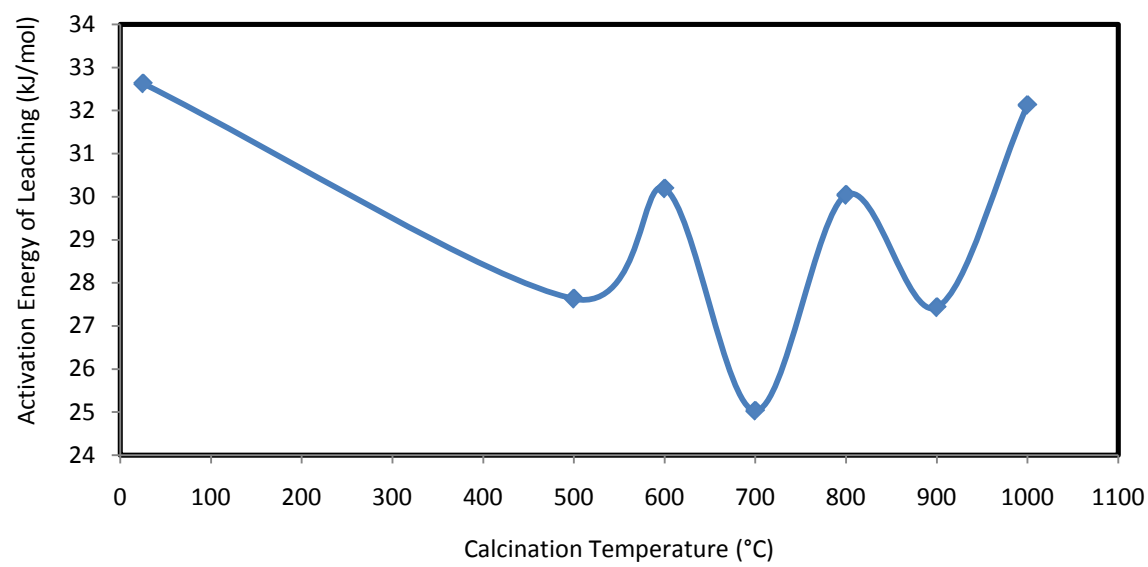

Figure 10. Effect of calcination temperature on activation energy of leaching for Ngwo clay leached in $1 \mathrm{M} \mathrm{HCl}$ for 60 minutes contact time. 
barrier that must be surmounted for a reaction to occur; the lowering of this energy means that leaching reaction is made thermodynamically or energetically easier, thus enhancing reaction rates or kinetics. This explains why clay calcine produced at $700^{\circ} \mathrm{C}$ (holding for 60 minutes) yielded the highest solubility of alumina from the clay as shown by the \% $\mathrm{Al}$ in leach solution. It was also observed that the uncalcined sample of the clay required the highest activation energy of leaching $(32.63 \mathrm{~kJ} / \mathrm{mol})$; explaining why it was very difficult to leach alumina from such sample, as seen in its very low solubility data (\%Al taken into the leach solution). Thus, the alumina in uncalcined or unactivated clay is locked up in the clay chemistry, responding very sluggishly to acid attack. Similarly, clay sample calcined at $1000^{\circ} \mathrm{C}$ for 60 minutes recorded the next highest activation energy $(32.13 \mathrm{~kJ} / \mathrm{mol})$ after the uncalcined clay. Leaching of alumina was also difficult in this case because at $1000^{\circ} \mathrm{C}$, formation of crystalline phases had commenced. Thus, the alumina is again locked up in the mullite network, making it difficult for acid attack. Similar findings were reported in literature [38] [39] [40] [41]. As shown in Figure 10, activation energy varied between the extremes of the high values reported for the uncalcined clay at $\sim 25^{\circ} \mathrm{C}$ and those for samples calcined at $1000^{\circ} \mathrm{C}$; reaching the lowest value of $25.03 \mathrm{~kJ} / \mathrm{mol}$ at $700^{\circ} \mathrm{C}$. This means that the clay was transformed completely to an amorphous form at $700^{\circ} \mathrm{C}$. In other words, the clay was thermally activated for maximum leaching response at $700^{\circ} \mathrm{C}$ [28]. The alumina in the amorphous phase is therefore more soluble than that in the crystalline orsemi-crystalline phases that existed below and above $700^{\circ} \mathrm{C}$.

\section{Conclusions}

The thermal treatment conditions required for transforming Ngwo clay to metakaolinite and subsequent leaching of alumina were investigated. Different thermal treatments produced different degrees of leaching response from the clay based on the nature and degree of phase transformation. X-ray diffraction studies confirmed that the optimal leaching response corresponded with the thermal treatment that transformed the clay to an amorphous phase or metakaolinite. The clay was transformed from its low-temperature crystalline form to an amorphous form (at $700^{\circ} \mathrm{C}$ ) and then back to high-temperature crystalline phases. Prolonged heating (above 90 minutes) under isothermal conditions also caused the appearance of crystalline phases and loss of solubility. Best results were achieved under 60 minutes heating duration at $700^{\circ} \mathrm{C}$. Thermal treatment also affected the activation energy of leaching such that high solubility (high leaching response) corresponded with low activation energy. Thermally activated Ngwo clay can be used as alternative resource for alumina in Nigeria where bauxite is scarce or non-existent.

The present work has established the optimal calcination conditions for Ngwo clay. Further work is recommended to investigate the effects of the leaching variables such as clay particle size, acid concentration, leaching temperature, sol- 
id/liquid ratio of clayweight to acid volume, and shaking rate. This will establish the optimal leaching conditions for solubilizing the alumina in the clay. Methods of recovering alumina from the leach solution should also be investigated.

\section{Acknowledgements}

This work was funded by a research fellowship (REG/EST/SPMU/SP.2318) of the Federal University of Technology, Owerri. The authors would like to thank the unknown reviewers for their helpful comments and suggestions.

\section{Conflicts of Interest}

The authors declare no conflicts of interest regarding the publication of this paper.

\section{References}

[1] Hudson, K., Misra, C. and Wefers, K. (1997) Aluminium Oxide. In: Habashi, F., Ed., Handbook of Extractive Metallurgy, Volume II, Part 3: Light Metals, John Wiley \& Sons, Inc., New York, 1062-1068.

[2] Hudson, K., Misra, C. and Wefers, K. (1997) Bauxite, the Principal Alumina Raw Material. In: Habashi, F., Ed., Handbook of Extractive Metallurgy, Volume II, Part 3: Light Metals, John Wiley \& Sons, Inc., New York, 1068-1072.

[3] Hudson, K., Misra, C. and Wefers, K. (1997) Other Processes for Alumina Production. In: Habashi, F., Ed., Handbook of Extractive Metallurgy, Volume II, Part 3: Light Metals, John Wiley \& Sons, Inc., New York, 1091-1094.

[4] Hudson, L.K., Misra, C., Perrotta, A.J., Wefers, K. and Williams, F.S. (2011) Aluminum Oxide. In: Elvers, B., Ed., Ullman's Encyclopedia of Industrial Chemistry, 7th Edition, Wiley-VCH, Weiheim, 40 p.

[5] Habashi, F. (1995) Bayer's Process for Alumina Production: A Historical Perspective. Bulletin of Historical Chemistry, 17-18, 15-19.

[6] Habashi, F. (2005) A Short History of Hydrometallurgy. Hydrometallurgy, 79, 15-22. https://doi.org/10.1016/j.hydromet.2004.01.008

[7] United States Geological Survey (USGS) (2013) Bauxite and Alumina. In: Lee, E., Bray, L.M., White and Miller, L.D., Coms., 2013 Minerals Yearbook, Advance Release, $13 \mathrm{p}$.

[8] United States Geological Survey (USGS) (2015) Aluminium: Mineral Commodity Summaries. 16-17. (Compiled by E. Lee Bray) https://doi.org/10.3133/70140094

[9] United States Geological Survey (USGS) (2015) Bauxite and Alumina: Mineral Commodity Summaries. 26-27. (Compiled by E. Lee Bray) https://doi.org/10.3133/70140094

[10] United States Geological Survey (USGS) (2015) Bauxite and Alumina: Mineral Industry Surveys, First Quarter of 2015. 1-5. (Compiled by E. Lee Bray \& Linda M. Barnes)

[11] Schwarz, T. (1997) Distribution and Genesis of Bauxite on the Mambilla Plateau, SE Nigeria. Applied Geochemistry, 12, 119-131. https://doi.org/10.1016/s0883-2927(96)00058-3

[12] Petters, S.W. (1993) Metallic and Nonmetallic (Industrial) Minerals. In: Adalemo, I.A. and Baba, J.M., Eds., Nigeria: Giant in the Tropics, Volume 1: A Compendium, 
Gabuno Pub. Ltd., Lagos, 61.

[13] Obaje, N.G. (2009) Geology and Mineral Resources of Nigeria: Lecture Notes in Earth Sciences 120. Springer, London, 52, 118-119, 183-201. https://doi.org/10.1007/978-3-540-92685-6

[14] Wright, J.B., Hastings, D.A., Jones, W.B. and Williams, H.R. (1985) Geology and Mineral Resources of West Africa. George Allen \& Unwin Ltd., London, 35, 48-49, 87, 119, 145, 157. https://doi.org/10.1007/978-94-015-3932-6

[15] Malomo, S. (2011) Framework and Opportunities for Sustainable Private Sector Participation in Solid Minerals Development in Ekiti State. Ekiti State Economic Development Summit.

[16] Talabi, A.O., Ademilua, O.L., Ajayi, O.Z. and Ogunniyi, S.O. (2013) Preliminary Geophysical Evaluation of Orin Bauxite Deposit, Southwestern Nigeria. Journal of Emerging Trends in Engineering and Applied Sciences, 4, 432-437.

[17] Sada, M.M. (2013) Mid-Term Report for the Minerals and Metals Sector. Ministerial Platform Presented by Minister, Ministry of Mines and Steel Development (MMSD).

[18] Aliyu, A. (1996) Potentials of the Solid Minerals Industry in Nigeria. RMRDC, Abuja, 1-40, 63-83, 164-172.

[19] Pabalkar, V.V. (1999) Nigerian Aluminium Industry: Scope and Prospects. Proceedings of the 16th Annual Conference of the Nigerian Metallurgical Society (NMS), Abuja, 3rd-5th November 1999, 1-7.

[20] Okorie, B.A. (2000) The Metallurgical Industry and National Development. 2nd Annual NAMMES Conference Tagged “FUTO 2000”, Owerri, 16-17 March 2000, 8 p.

[21] Adeniji, G. (2009) An Overview of Nigeria's Solid Minerals Sector. Accenture Knowledge Event, 1-10.

[22] Fejokwu, L.C. (1996) Nigeria: A Viable Black Power. Volume 2: Resources, Potentials and Challenges. Polcom Press, Lagos, 375-385.

[23] Barsoum, M.W. (2003) Fundamentals of Ceramics. 2nd Edition, IOP Publishing Ltd., Bristle, 70-74. https://doi.org/10.1887/0750309024

[24] Shackelford, J.F. (2015) Introduction to Materials Science for Engineers. 8th Edition, Pearson Higher Education Inc., Upper Saddle River, 71-72.

[25] Attah, L.E. and Oden, M.I. (2010) Physico-Chemical Properties and Industrial Potential of Some Clay Deposits in Calabar Area, South Eastern Nigeria. Global Journal of Environmental Sciences, 9, 39-49.

[26] Velde, B. (1995) Composition and Mineralogy of Clay Minerals. In: Velde, B., Ed., Origin and Mineralogy of Clays. Clays and the Environment, Springer, Verlag, 8-29. https://doi.org/10.1007/978-3-662-12648-6_2

[27] Mark, U. and Onyemaobi, O.O. (2009) Assessment of the Industrial Potentials of Some Nigerian Kaolinitic Clay Deposits. International Research Journal in Engineering, Science \& Technology, 6, 77-84.

[28] Chakraborty, A.K. (2014) Phase Transformations of Kaolinite Clay. Springer, New Delhi, 3-12, 43-47, 185-206, 327-329. https://doi.org/10.1007/978-81-322-1154-9

[29] Velde, B. (1992) Introduction to Clay Minerals: Chemistry, Origins, Uses and Environmental Significance. Chapman \& Hall, London, 1-17, 55-82, 96.

[30] Fahrenholtz, W.G. (2008) Clays. In: Shackelford, J.F. and Doremus, R.H., Eds., Ceramic and Glass Materials. Structure, Properties and Processing, Springer, New 
York, 111-133. https://doi.org/10.1007/978-0-387-73362-3_7

[31] Kaolinite (2015) In Wikipedia. https://en.wikipedia.org/w/index.php?title=Kaolinite\&oldid=693335566

[32] Duval, D.J., Risbud, S.H. and Shackelford, J.F. (2008) Mullite. In: Shackelford, J.F. and Doremus, R.H., Eds., Ceramic and Glass Materials. Structure, Properties and Processing, Springer, New York, 27-39. https://doi.org/10.1007/978-0-387-73362-3_2

[33] Lamberov, A.A., Sitnikova, E.Yu. and Abdulga, A.Sh. (2012) Kinetic Features of Phase Transformation of Kaolinite into Metakaolinite for Kaolin Clays from Different Deposits. Russian Journal of Applied Chemistry, 85, 892-897. https://doi.org/10.1134/S1070427212060109

[34] Ghosh, A. and Ghosh, S. (2014) A Textbook of Metallurgical Kinetics. PHI Learning Private Ltd., Delhi, 1-10, 82-100, 151-185, 301-319.

[35] Gupta, C.K. (2003) Chemical Metallurgy: Principles and Practice. Wiley-VCH Verlag GmbH \& Co., Weinheim, 31-52, 459-499.

[36] Rao, S.R.R. (2006) Hydrometallurgical Processes. In: Resource Recovery and Recycling from Metallurgical Wastes, Waste Management Series Volume 7, Elsevier Science, Oxford, Chapter 4, 71-108.

[37] Brown, T.L., LeMay Jr., H.E., Bursten, B.E., Murphy, C.J. and Woodward, P.M. (2012) Chemistry: The Central Science. 12th Edition, Pearson Education Inc., New York, 512-655.

[38] Al-Zahrani, A.A. and Abdul-Majid, M.H. (2009) Extraction of Alumina from Local Clays by Hydrochloric Acid Process. Engineering Science: Journal of King Abdulaziz University, 20, 29-41.

[39] Al-Ajeel, A.W.A. and Al-Sindy, S.I. (2006) Alumina Recovery from Iraqi Kaolinitic Clay by Hydrochloric Acid Route. Iraqi Bulletin of Geology and Mining, 2, 67-76.

[40] Ajemba, R.O. and Onukwuli, O.D. (2012) Determination of the Optimum Dissolution Conditions of Ukpor Clay in Hydrochloric Acid Using Response Surface Methodology. International Journal of Engineering Research and Applications, 2, 732-742.

[41] Udeigwe, U., Onukwuli, O.D., Ajemba, R. and Ude, C.N. (2015) Kinetic Studies of Hydrochloric Acid Leaching of Alumina from Agbaja Clay. International Journal of Research in Advanced Engineering and Technology, 1, 64-72. 